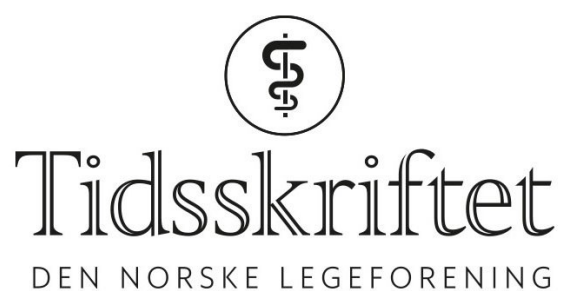

DEN NORSKE LEGEFORENING

\title{
Hvordan møte helseadelen?
}

KOMMENTAR

\section{TORGEIR BRUUN WYLLER}

E-post: t.b.wyller@medisin.uio.no

Torgeir Bruun Wyller er professor i geriatri og styreleder i Helsetjenesteaksjonen.

Ingen oppgitte interessekonflikter.

Rune Slagstad fortjener stor takk for at han formidler så detaljert kunnskap om de viktige, men tilsynelatende uforståelige prosessene, som har gått for seg i norsk helsepolitikk de siste par tiårene (1). Hans gjennomgang gir større forståelse for vesentlige, men til nå lite omtalte utviklingstrekk i moderne norsk historie, og for hvordan vi er havnet der vi er.

Slagstad levner liten tvil om at han er bekymret for den helsepolitiske utviklingen som den nye helseadelen står bak. Det er det ikke vanskelig å være enig i. Et naturlig neste spørsmål som det neppe var rom for å drøfte i denne omgangen - ville være hvordan det er mulig å påvirke kursen i en mer gunstig retning. Slagstad viser med all mulig tydelighet at maktutøvelsen ofte er skjult, at de reelle makthaverne er lite interessert i åpne prosesser, og at de regulære politiske organene for en stor del bedriver spill for galleriet. Dette har konsekvenser for hvilke mottrekk som kan være effektive.

Helsetjenesteaksjonen (2), som Slagstad nevner i forbifarten, arbeider kontinuerlig med denne problemstillingen. Vi er kommet til at mottrekk mot helseadelen grovt sett må følge to hovedspor. For det første å vise at det er usant når helseadelens medlemmer hevder at det ikke finnes alternativer til dagens politikk, eller at alternativene ville blitt alt for dyre. Det gjør vi gjennom grundig, vederheftig og tidkrevende analyse (3). For det andre er det nødvendig å etablere motmakt. Velferdsordningene som ble kjempet frem i første halvpart av forrige århundre ville for eksempel ikke blitt som de ble hvis ikke arbeiderbevegelsen hadde vært gjennomsyret av samhold, kampvilje og disiplin. På tilsvarende måte vil det ikke være mulig å slå ring om en offentlig helsetjeneste av høy kvalitet for alle, og verne den mot vanstyre, overbyråkratisering og kvasiøkonomisk abrakadabra, uten å etablere kampvilje, samhold, og strategiske allianser.

\section{LITTERATUR:}

1. Slagstad R. Den nye helseadelen. Tidsskr Nor Legeforen 2017; 137: 1058 - 64 .

2. Helsetjenesteaksjonen. www.htaksjonen.org/ (21.9.2017).

3. Haukelien H, Wyller TB. Ny helsepolitikk - det finnes løsninger. Oslo: Dreyers forlag, 2017. 
(ㅇ) Tidsskrift for Den norske legeforening 2020. Lastet ned fra tidsskriftet.no 